\title{
Macroinvertebrates of the Iranian running waters: a review
}

Macroinvertebrados de águas correntes do Irã: uma revisão

\author{
Moslem Sharifinia ${ }^{1}$ \\ ${ }^{1}$ Department of Marine Biology, College of Sciences, Hormozgan University, \\ Minab Road, Bandar Abbas 3995, Iran \\ e-mail: moslem.sharifinia@yahoo.com
}

\begin{abstract}
A comprehensive review of macroinvertebrate studies conducted along the Iranian running waters over the last 15 years has been made by providing the most updated checklist of the Iranian running waters benthic invertebrates. Running waters ecosystems are complex environments known for their importance in terms of biodiversity. As part of the analysis, we endeavored to provide the critical re-identification of the reported species by through comparisons with the database of the Animal Diversity Web (ADW) and appropriate literature sources or expert knowledge. A total of 126 species belonging to 4 phyla have been compiled from 57 references. The phylum Arthropoda was found to comprise the most taxa $(\mathrm{n}=104)$ followed by Mollusca, Annelida and Platyhelminthes. Ongoing efforts in the Iranian running waters regarding biomonitoring indices development, testing, refinement and validation are yet to be employed in streams and rivers. Overall, we suggest that future macroinvertebrate studies in Iranian running waters should be focused on long-term changes by broadening target species and strong efforts to publish data in peer-reviewed journals in English.
\end{abstract}

Keywords: biodiversity; biomonitoring; assessment; freshwater ecosystems.

Resumo: Este trabalho contém uma ampla revisão sobre os estudos de macroinvertebrados realizados em águas correntes iranianas ao longo dos últimos 15 anos com o objetivo de fornecer um checklist de invertebrados bentônicos. Ecossistemas de águas correntes são ambientes complexos e conhecidos por sua importância para a biodiversidade. Como parte da análise, nós nos esforçamos para oferecer uma re-identificação crítica das espécies encontradas comparando-as com o banco de dados da Animal Diversity Web (ADW) e com fontes bibliográficas adequadas ou conhecimento especializado. Um total de 126 espécies de 4 filos foram compiladas em 57 publicaçôes. O filo Arthropoda é o que contém o maior número de taxa $(\mathrm{n}=104)$, seguido de Mollusca, Annelida e Platyhelminthes. Os esforços atuais em ambientes aquáticos do Irã estáo relacionados ao desenvolvimento de índices de biomonitoramento, testes, refinamento e validação para serem utilizados em córregos e rios. Em uma visão geral, nós sugerimos que estudos futuros sobre macroinvertebrados em águas iranianas devam ser focados em mudanças de longo prazo, na ampliação do conhecimento de espécies-alvo e em fazer fortes esforços para publicar os resultados em revistas científicas na língua inglesa.

Palavras-chave: biodiversidade; biomonitoramento; avaliação; ecossistemas de água doce. 


\section{Introduction}

Riverine ecosystems are complex environments known for their importance in terms of biodiversity (McCluney et al., 2014). However, human activities (pollution, tourism, commercial fisheries, eutrophication, sediment discharge and sand extraction) have directly and indirectly affected the biodiversity of these ecosystems on a worldwide scale (Wei \& He, 2012; Goudie, 2013; Kim et al., 2015; McCluney et al., 2014).

There is a vastly extended network of rivers in Iran most of which seasonally are filled with water. Some permanent rivers run from the Alborz or the Zagros to the Caspian Sea, Persian Gulf and Oman Sea. Some temporary rivers either run into a body of water or get dried before reaching any watershed. The major rivers running into the Caspian Sea in Iranian shorelines flow from the northern Alborz attitudes like: Aras, Sefid Rud, Chalus, Haraz, Sehezar, Babol, Talar, Tajan, Gorgan, Atrak, Qarasu and Neka. The Zagros serves as the main originating headspring of the rivers running into the Persian Gulf and Oman sea watersheds. Among all these rivers, the major ones are: Arvand Rud, Gamasb, Karun, Jarahi, Zohreh, Dalaki, Mend, Shur, Minab, Mehran and Naband (Mehraby, 2010).

The geographical location of Iran shows that about $80 \%$ of the total area is located in an arid or semi-arid zone (Aminmansour, 2007). As a result of the following factors, land degradation and desertification have accelerated in Iran during the recent decades: first, the population has doubled over the last 25 years (since 1979); second, increased agricultural and pastoral products have forced people to use land extensively or convert forest and rangelands to cultivated land (Aminmansour, 2007). Therefore, these activities have a major affect on the water quality and diversity of aquatic plants and animals. However, the full extent of the knowledge on river species composition and the distribution of benthic invertebrates in Iranian running waters that has accumulated over the past 15 years (2000-2015) have not been documented in an integrated manner, in spite of the great progress having been achieved during this period of time.

The study of macroinvertebrate assemblages allows the assessment of the ecological quality of river and stream ecosystems (Munné \& Prat, 2011; Paller et al., 2014). The macroinvertebrate plays a fundamental role in sediment processes, providing an important measure of the response of a community to environmental stressors (Adámek \& Maršálek, 2013; Johnson \& Ringler, 2014) and exhibiting the greatest potential for monitoring conditions at a particular station (Sharifinia et al., 2012a; Chang et al., 2014). Given the ability of reflecting water quality, a growing number of tools and methods rely on macroinvertebrate attributes, such as species composition, abundance, biomass and ecological function (Aparicio et al., 2011; Menetrey et al., 2011; Moya et al., 2011; Weigel \& Dimick, 2011; Perera et al., 2012).

This review is an attempt to make our data on the macroinvertebrate richness of the Iranian running waters available to global comparisons. In the present study, we first aimed to update the list of benthic macroinvertebrates found in the Iranian running waters, being supported by critical taxonomy of the previously reported taxa. Accordingly, the spatial and temporal distribution of benthic macroinvertebrates could be overviewed in terms of biogeography, by highlighting faunal assemblages that reflects a habitat classification. In particular, the habitat classification based on species occurrences toward regional distribution characteristics are carefully addressed in semi-quantitative manner. Finally, the outlook for future researches supporting the sound science toward ecosystem-based management of the Iranian running waters was suggested, by emphasizing the socio-ecological value of river benthic diversity.

\section{Data Collection and Analysis of the Macroinvertebrates in Iran}

To provide a list of the macroinvertebrate species reported in the Iranian running waters, the occurrence and distribution were analyzed based on the data collected from previous works. A total of 57 peer-reviewed articles on macroinvertebrate assemblages in river and stream ecosystems of Iranian running waters, have been published since 2000 (Figure 1).

Taxa identified to genus or species level are categorized in phyla, to fully update the list of riverine macroinvertebrates. A total of 126 species belonged to 158 genus, 97 families, 25 orders and 7 classes are reported in the Iranian running waters. As part of the analysis, we endeavored to provide the critical re-identification of the reported species by comparisons with the database of the Animal Diversity Web (ADW) and appropriate literature sources or expert judgment (Table 1). 


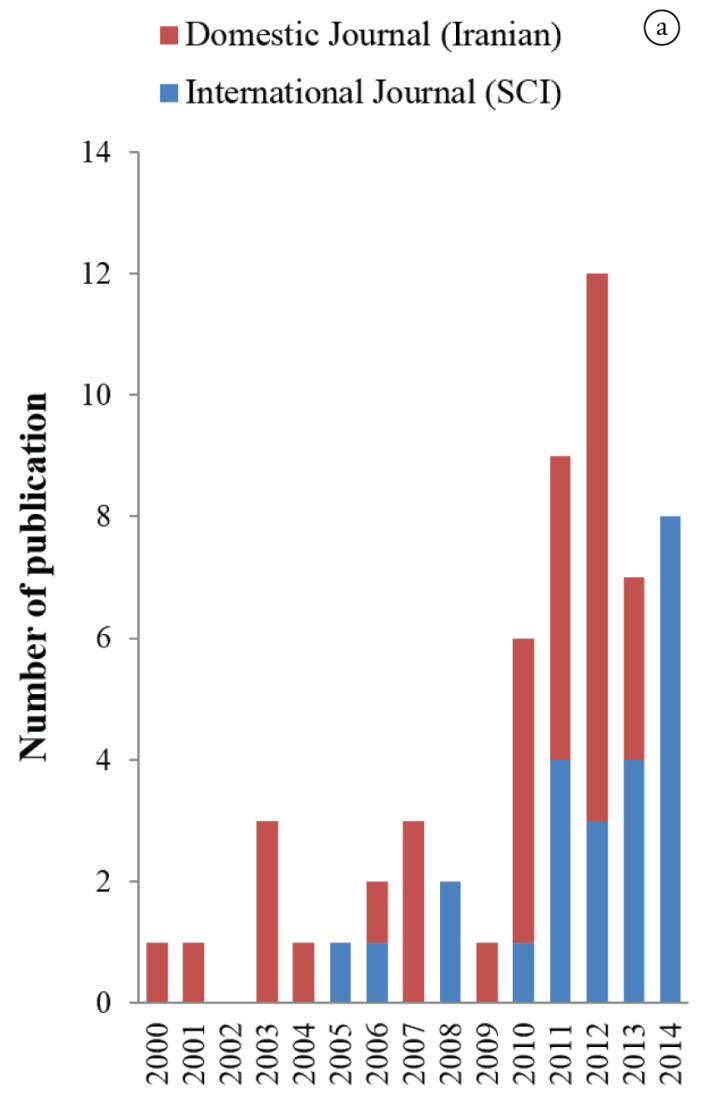

Publication Year

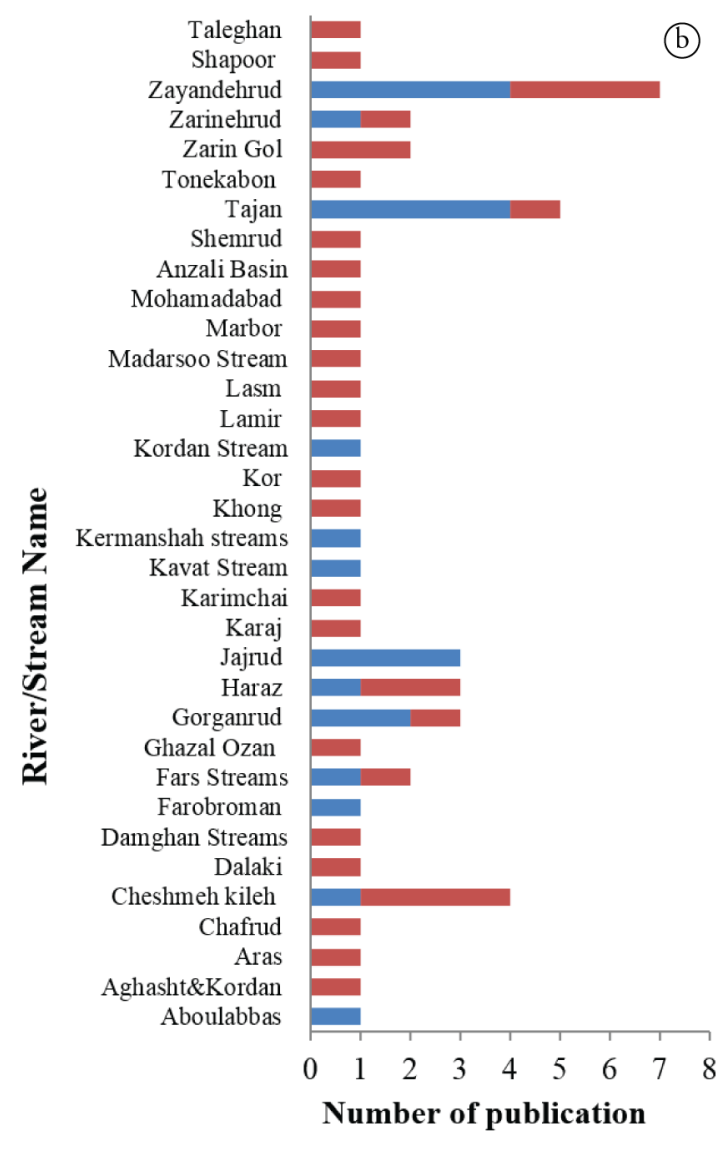

Figure 1. The overview on macroinvertebrate studies conducted at the Iranian running waters; (a) yearly number of publications over the past 15 years, and (b) the number of publications referring to 35 rivers and streams with corresponding references, a total of 57 reviewed articles. References: Abbasi et al. (2013a, b), Abbaspoor et al. (2011), Abbaspoor et al. (2013a, b), Abbaspoor et al. (2012), Abbaspour et al. (2013), Ahmadi et al. (2000), Ahmadi et al. (2012), Aliyev \& Ahmadi (2010), Amri et al. (2014), Ardalan et al. (2011), Babapoor et al. (2011), Bashti \& Ostovan (2014), Ebrahimnejad (2003a, b), Ebrahimnejad \& Nikoo (2004), Ebrahimnezhad \& Fakhri (2005), Farasat \& Sharifi (2014), Farhangi \& Taimoori Yansari (2012), Gahane et al. (2006), Ghasemi \& Kamali (2014), Hafeziyeh (2001), Haffar et al. (2010), Hatami et al. (2011a, b), Hosyni et al. (2012), Hosyni \& Nejad (2014), Jorjani et al. (2008), Kamali \& Esmaeilisari (2009), Kamali et al. (2010), Kamali \& Tatina (2010), Khatami \& Shayegan (2006), Khatami et al. (2007), Mesgarankarimi et al. (2012a, b), Mirrasouli et al. (2012a, b), Mirzajani et al. (2008), Montajami et al. (2012), Naderi Jolodar et al. (2011), Nadushan \& Ramezani (2011), Namin et al. (2013), Navan Maghsoodi (2012), Navan Maghsoodi et al. (2003), Ostovan \& Niyakan (2007), Pazira et al. (2008), Raoshan Tabari et al. (2013), Shapoori et al. (2010), Sharifinia et al. (2012a, b), Shokri et al. (2014), Soltani et al. (2012), Soofiani et al. (2012), Toosi et al. (2011), Varnosfaderany et al. (2010), Yazdian et al. (2014).

\section{Scientific Efforts as to Macroinvertebrate Studies in Iran}

An analysis is done as to yearly number of publications, the study area of interest, and the area of interest per locality (35 river and streams along 13 provinces). Such a combinatorial analysis will help the understanding of the Iranian running water macroinvertebrates in terms of species diversity and biogeography in a historical manner.

With regard to the number of studies (Figure 1), only two articles had been published until the 2003 .
Since the first report in 2000, then publications rapidly increased afterwards. The increasing trend in publishing articles in the recent years, indicate the increased scientific efforts given on the river and stream ecology in Iranian running waters. Indeed more than half of the studies were published from 2010 onwards. During the relevant period (2000-2010), the majority of these studies have been published in the local journals hence could not be available to the international audiences. Only 4 articles were published in internationally journals (Figure 1). This first published article in 2005 
Table 1. List of suggested identification for macroinvertebrates found in the Iranian running waters, being updated based on the Animal Diversity Web (ADW) and appropriate literature references.

\begin{tabular}{|c|c|c|c|c|c|}
\hline Phylum & Class & Order & Family & Genus & Species \\
\hline \multirow[t]{14}{*}{ Annelida } & Oligochaeta & Opisthopora & Lumbricidae & Aporrectodea & A. rosea \\
\hline & & & & Eiseniella & E. tetraedra \\
\hline & Clitellata & Arhynchobdellida & Erpobdellidae & Erpobdella & \\
\hline & & Rhynchobdellida & Piscicolidae & Piscicola & \\
\hline & & & Glossiphoniidae & Glossiphonia & \\
\hline & & & & Helobdella & \\
\hline & & & & Hemiclepsis & \\
\hline & & Lumbriculida & Lumbriculidae & Limnodrilus & \\
\hline & & & & Lumbriculus & \\
\hline & & & & Stylodrilus & \\
\hline & & Haplotaxida & Haplotaxidae & Haplotaxis & \\
\hline & & & Naididae & Pristina & \\
\hline & & & Naididae & Nais & $\begin{array}{l}\text { N. communis } \\
\text { N. elinguis }\end{array}$ \\
\hline & & & Tubificidae & $\begin{array}{l}\text { Peloscolex } \\
\text { Tubifex }\end{array}$ & \\
\hline \multirow[t]{16}{*}{ Mollusca } & Gastropoda & Basommatophora & Planorbidae & Planorbis & \\
\hline & & Mesogastropoda & Bithyniidae & Bithynia & B. tentaculata \\
\hline & & Hygrophila & Physidae & Physa & $\begin{array}{l}\text { P. concolor } \\
\text { P. hordacea }\end{array}$ \\
\hline & & & & Costatella & C. acuta \\
\hline & & Basommatophora & Lymnaeidae & Lymnaea & L. glabra \\
\hline & & & & & $\begin{array}{l}\text { L. truncatula } \\
\text { L. auricularia } \\
\text { L. stagnalis }\end{array}$ \\
\hline & & Heterostropha & Valvatidae & Valvata & $\begin{array}{l}\text { V. mergella } \\
\text { V. sincera } \\
\text { V. cristata }\end{array}$ \\
\hline & & Littorinimorpha & Hydrobiidae & Potamopyrgus & P. antipodarum \\
\hline & & Pulmonata & Planorbidae & Planorbis & \\
\hline & & & Lymnaeidae & & \\
\hline & & Stylommatophora & $\begin{array}{l}\text { Ancylidae } \\
\text { Succineidae }\end{array}$ & Succinea & \\
\hline & & Caenogastropoda & Thiaridae & Melanopsis & M. tuberculata \\
\hline & Bivalvia & Veneroida & Corbiculidae & Corbicula & C. fluminea \\
\hline & & & Sphaeriidae & Pisidium & P. amnicum \\
\hline & & & & Sphaerium & $\begin{array}{l}\text { S. corneum } \\
\text { S. rivicola }\end{array}$ \\
\hline & & & Dreissenidae & Dreissena & D. polymorpha \\
\hline \multirow[t]{4}{*}{ Platyhelminthes } & Turbellaria & Tricladida & Planariidae & Polycelis & P. felina \\
\hline & & & & Phagocata & \\
\hline & & & Dendrocoelidae & & \\
\hline & & Seriata & Planariidae & & \\
\hline
\end{tabular}

\begin{tabular}{|c|c|c|c|c|c|c|}
\hline $\begin{array}{l}\text { Phylum } \\
\text { Arthropoda } \\
\text { Class } \\
\text { Malacostraca }\end{array}$ & & & & & & \\
\hline Order & Family & Genus & Species & & & \\
\hline $\begin{array}{c}\text { Amphipoda } \\
\text { Class } \\
\text { Insecta }\end{array}$ & Gammaridae & Gammarus & G. daiberi & & & \\
\hline Order & Family & Genus & Species & Family & Genus & Species \\
\hline Diptera & $\begin{array}{c}\text { Athericidae } \\
\text { Blephariceridae }\end{array}$ & $\begin{array}{c}\text { Atherix } \\
\text { Bibiocephala }\end{array}$ & $\begin{array}{l}\text { A. basilica } \\
\text { B. grandis }\end{array}$ & $\begin{array}{c}\text { Tanytarsus } \\
\text { Tvetenia }\end{array}$ & & \\
\hline
\end{tabular}


Table 1. Continued...

\begin{tabular}{|c|c|c|c|c|c|c|c|}
\hline Order & Family & \multicolumn{2}{|c|}{ Genus } & Species & Family & Genus & Species \\
\hline & \multirow{40}{*}{ Chironomidae } & \multirow{3}{*}{\multicolumn{2}{|c|}{ Liponeura }} & B. infuscate & Tanytarsus & & \\
\hline & & & & B.minor & Tvetenia & & \\
\hline & & & & & Simuliidae & Simulium & S. damnosum \\
\hline & & \multirow{4}{*}{\multicolumn{2}{|c|}{ Aagaardia }} & A. longicalcis & & & S. venustum \\
\hline & & & & A. oksanae & Psychodidae & Telmatoscopus & T. aberrans \\
\hline & & & & A. protensa & & & T. advenus \\
\hline & & & & A. sivertseni & & Pericoma & \\
\hline & & \multirow{3}{*}{\multicolumn{2}{|c|}{$\begin{array}{l}\text { Abiskomyia } \\
\text { Ablabesmyia }\end{array}$}} & A. paravirgo & Empididae & Chelifera & C. accomodata \\
\hline & & & & A. digitata & & & C. caliga \\
\hline & & & & A. ensiceps & & Hemerodromia & H. acutata \\
\hline & & \multirow{3}{*}{\multicolumn{2}{|c|}{ Tanytarsini }} & T. antennata & & & H. basalis \\
\hline & & & & T. atridorsum & Dixidae & Dixa & D. abiettica \\
\hline & & & & T. dimidiatus & & & D. cincta \\
\hline & & \multicolumn{2}{|c|}{ Clunio } & C. tuthill & Stratiomyidae & Euparyphus & E. apicalis \\
\hline & & \multicolumn{2}{|c|}{ Doithrix } & D. barberi & & & E. mutabilis \\
\hline & & \multicolumn{2}{|c|}{ Chironomus } & & Tabanidae & Tabanus & T. abaculus \\
\hline & & \multicolumn{2}{|c|}{ Ablabesmyia } & & & & T. atratus \\
\hline & & \multicolumn{2}{|c|}{ Brillia } & & Tipulidae & Tipula & T. absona \\
\hline & & \multicolumn{2}{|c|}{ Cardiocladius } & & & & T. paludosa \\
\hline & & \multicolumn{2}{|c|}{ Cladotanytarsus } & & & Antocha & A. aculifera \\
\hline & & \multicolumn{2}{|c|}{ Cricotopus } & & & & A. biacus \\
\hline & & \multicolumn{2}{|c|}{ Cryptochironomus } & & & Dicranota & \\
\hline & & \multicolumn{2}{|c|}{ Demicryptochironomus } & & & Nephrotoma & \\
\hline & & \multicolumn{2}{|c|}{ Dicrotendipes } & & Culicidae & Culicidae & C. cuprinervis \\
\hline & & Kieffe & rulus & & Ceratopogonidae & Allohelea & A. annulata \\
\hline & & Lappo & mittia & & & & A. fruticosa \\
\hline & & Microchi & onomus & & & Bezzia & \\
\hline & & Microte & ndipes & & Dolichopodidae & Acropsilus & A. albitibia \\
\hline & & Nanoc & ladius & & & & A. maprik \\
\hline & & Orthoc & ladius & & Mycetophilidae & Rhymosia & \\
\hline & & Parametric & cenemus & & Cecidomyiidae & Parepidosis & \\
\hline & & Paraphae & nocladius & & Chamaemyiidae & Cecidomyia & \\
\hline & & Paratan & ytarsus & & Pediciidae & Dicranota & \\
\hline & & Parate & ndipes & & Stratiomyidae & & \\
\hline & & Phaeno & osectra & & Rhagionidae & & \\
\hline & & Polype & dilum & & Dolichopodidae & & \\
\hline & & Procl & adius & & Chaoboridae & Chaoborus & C. crystallinus \\
\hline & & Rheop & elopia & & & & C. punctipennis \\
\hline & & Rheotar & ytarsus & & Thaumaleidae & & \\
\hline & & Tany & pus & & & & \\
\hline Order & Family & Genus & Species & Order & Family & Genus & Species \\
\hline Plecoptera & Capniidae & Capnia & C. arensi & Ephemeroptera & Baetidae & Baetis & B. adonis \\
\hline & & & C. bicomata & & & & B. bicaudatus \\
\hline & & & C. barberi & & & & B. alius \\
\hline & Chloroperlidae & Chloroperla & C. acuta & & & & B. magnus \\
\hline & & & C. stenoptila & & & & B. notos \\
\hline & & & C. zhiltzovae & & & & B. persecutor \\
\hline & & & $\begin{array}{c}\text { C. } \\
\text { tripunctata }\end{array}$ & & & & B. tricaudatus \\
\hline & Perlodidae & Isoperla & I. acula & & & & B. rhodani \\
\hline & & Isogenoides & I. olivaceus & & & Cloeon & C. Simile \\
\hline & & & I. zionensis & & & & C. dipterum \\
\hline & & & I. colubrinus & & & & C. cognatum \\
\hline & & & 1. doratus & & & Heterocloeon & \\
\hline & & & I. hansoni & & & Centroptilum & \\
\hline & & & l. krumholzi & & Heptageniidae & Epeorus & E. albertae \\
\hline
\end{tabular}


Table 1. Continued...

\begin{tabular}{|c|c|c|c|c|c|c|c|}
\hline Order & Family & Genus & Species & Order & Family & Genus & Species \\
\hline & & Perlodes & & & & & E. fragilis \\
\hline & Perlidae & Caroperla & C. Pacifica & & & & E. Hesperus \\
\hline & & Perla & & & & & E. grandis \\
\hline & & Đsoperla & $\begin{array}{c}Đ . \\
\text { grammatica }\end{array}$ & & & Rhithrogena & R. exilis \\
\hline & Leuctridae & Leuctra & L. aculeata & & & & R. ingalik \\
\hline & & & L. albida & & & Maccaffertium & \\
\hline & & & L. alpine & & & Heptagenia & \\
\hline & & & L. alta & & & Rhithrogena & \\
\hline & & & L. balcanica & & Caenidae & Caenis & C. tardata \\
\hline & & & L. alosi & & & Brachycercus & \\
\hline & & Capnia & & & Leptophlebiidae & Paraleptophlebia & P. adoptiva \\
\hline & Dytiscidae & Laccophilus & & & & & P. clara \\
\hline & Elmidae & Narpus & & & & & P. debilis \\
\hline & Nemouridae & Protonemura & & & Oligoneuriidae & Lachlania & L. fusca \\
\hline & & Nemoura & & & & & L. lucida \\
\hline & & Amphinemura & A. sulcicollis & & & & L. iops \\
\hline & Taeniopterygidae & Taeniopteryx & & & & Oligoneuriella & \\
\hline \multirow[t]{9}{*}{ Hemiptera } & Veliidae & Velia & $\begin{array}{c}V . \\
\text { heteroptera }\end{array}$ & & Ephemeridae & Ephemerella & E. doris \\
\hline & Corixidae & Micronecta & & & & & E. ignita \\
\hline & & Corixa & & & & Ephemera & E. danica \\
\hline & & Sigara & S. dorsalis & & Ecdyonuridae & Ecdyonurus & \\
\hline & Gerridae & & & & Polymitarcyidae & Campusurus & C. notatus \\
\hline & Nepidae & Nepa & N. cinerea & & Potamanthidae & & \\
\hline & & Ranatra & R. linearis & Trichoptera & Hydropsychidae & Cheumatopsyche & \\
\hline & Hydrometridae & Hydrometra & & & & Hydropsyche & \\
\hline & Pleidae & & & & & Ceratopsyche & \\
\hline \multirow[t]{13}{*}{ Odonata } & Coenagrionidae & Argia & A. adamsi & & & Potamyia & \\
\hline & & Ischnura & & & Rhyacophilidae & Rhyacophila & \\
\hline & & $\begin{array}{l}\text { Coenagrion } \\
\text { mercuriale }\end{array}$ & $\begin{array}{c}C . \\
\text { mercuriale }\end{array}$ & & Sericostomatidae & Sericostoma & \\
\hline & & & $\begin{array}{c}C . \\
\text { hastulatum }\end{array}$ & & Hydroptilidae & Agraylea & \\
\hline & Aeshnidae & Aeshna & A. affinis & & & Hydroptila & \\
\hline & & & A. athalia & & & Oxyethira & \\
\hline & Cordulegastridae & Cordulegaster & & & Philopotamidae & Chimarra & \\
\hline & Gomphidae & Gomphus & $\begin{array}{c}G . \\
\text { vulgatissimus }\end{array}$ & & & Philopotamus & \\
\hline & Calopterygidae & & & & Phryganeidae & Agrypnia & \\
\hline & Corduliidae & Somatochlora & & & Polycentropodidae & Polycentropus & \\
\hline & Libellulidae & & & & Brachycentridae & Brachycentrus & \\
\hline & Agriidae & Agrion & A. splendens & & Leptoceridae & Adicella & \\
\hline & Platycnemididae & & & & Ecnomidae & & \\
\hline \multirow[t]{6}{*}{ Hymenoptera } & Formicidae & Formica & & & Glossosomatidae & Glossossoma & \\
\hline & & & & & & Agapetus & \\
\hline & & & & & Limnephilidae & Limnephilus & L. Iunatus \\
\hline & & & & & & & L. flavicornis \\
\hline & & & & & Psychomyiidae & & \\
\hline & & & & & & L. flavicornis & \\
\hline
\end{tabular}

was about on macroinvertebrates in Iranian rivers aiming to estimate biomass and productivity in the Aghasht and Kordan Rivers (Ahmadi et al., 2000).

The analysis has shown that most of the studies have been conducted in provinces where universities where research was done in this field of Fisheries and Aquatic Ecology are existed, such as in the provinces of Tehran, Guilan, Mazandaran and Esfahan (Figure 2). Most of these studies are focused on the bioassessment and the effect of human activities on rivers and streams based on biotic indices. All of these studies have been done 
on a local scale (Case studies). Only two studies at a large-scale (20 and 17 headstreams across the entire province) have been conducted on the distribution and diversity of macroinvertebrates in Fars and Kermanshah provinces (Khatami \& Shayegan, 2006; Hafeziyeh, 2001). Finally looking at the study intensity cross the regional locality (Figures 1 and 2); the Zayandehrud River (Esfahan province) and Tajan River (Mazandaran province) seemed to be most intensively targeted with 7 and 5 publications, respectively. The high degree of study efforts given to this locality would be explained by the fact that it encompasses the most important rivers of the Iranian running waters. A further reason would be the increasing and continuing concerns on the Zayandehrud and Tajan Rivers, which has been a long standing issue of the environmental pollution and human activities.

\section{Chronological Studies on the Macroinvertebrates in Iranian Running Waters}

The study of the macroinvertebrate from the Iranian running waters based on published articles is dated back to the 1990s. In the 1990s (1995-96) one investigation was made on the determination of the biomass and production of macroinvertebrates in Aghasht and Kordan Rivers, in the Tehran province (see Ahmadi et al., 2000). Ahmadi et al. (2000) were reported 35 genera belonging to 30 families from the Aghasht and Kordan Rivers, whit aquatic insect larvae being the most frequent $(98.68 \%$ of the total abundance). Later, Hafeziyeh (2001) investigated aquatic insecta community in the Fars headstreams and provided a list of 48 identified genera. So, in 2003 two investigations were conducted to assess the production potential using benthic abundances and diversity in Siahkal Shemrood River and macroinvertebrate diversity and abundance and biotic indices in Zayandehrud River, were identified respectively 28 and 26 genera belong to aquatic insecta (Ebrahimnejad, 2003a; Navan Maghsoodi et al., 2003). The latter study conducted in 2003-04 addressed the taxonomic identification and distribution of macroinvertebrates in Marbor River (Ebrahimnejad \& Nikoo, 2004). To be noted, all the above studies were published in domestic journals, hence being expected a limited access to international audience. These pioneering studies would be regarded as the birth of macroinvertebrate research in the Iranian running waters, and in inland aquatic ecological history.

The running waters ecological studies in Iran further included the anthropogenic influences, primarily pollution, as a response to environmental pressure by rapid industrialization. The most controversial issue was the decline in water quality due to the construction of fish farms, sand extraction from rivers and sewage discharge (Abbaspoor et al., 2012; Soltani et al., 2012; Namin et al., 2013;

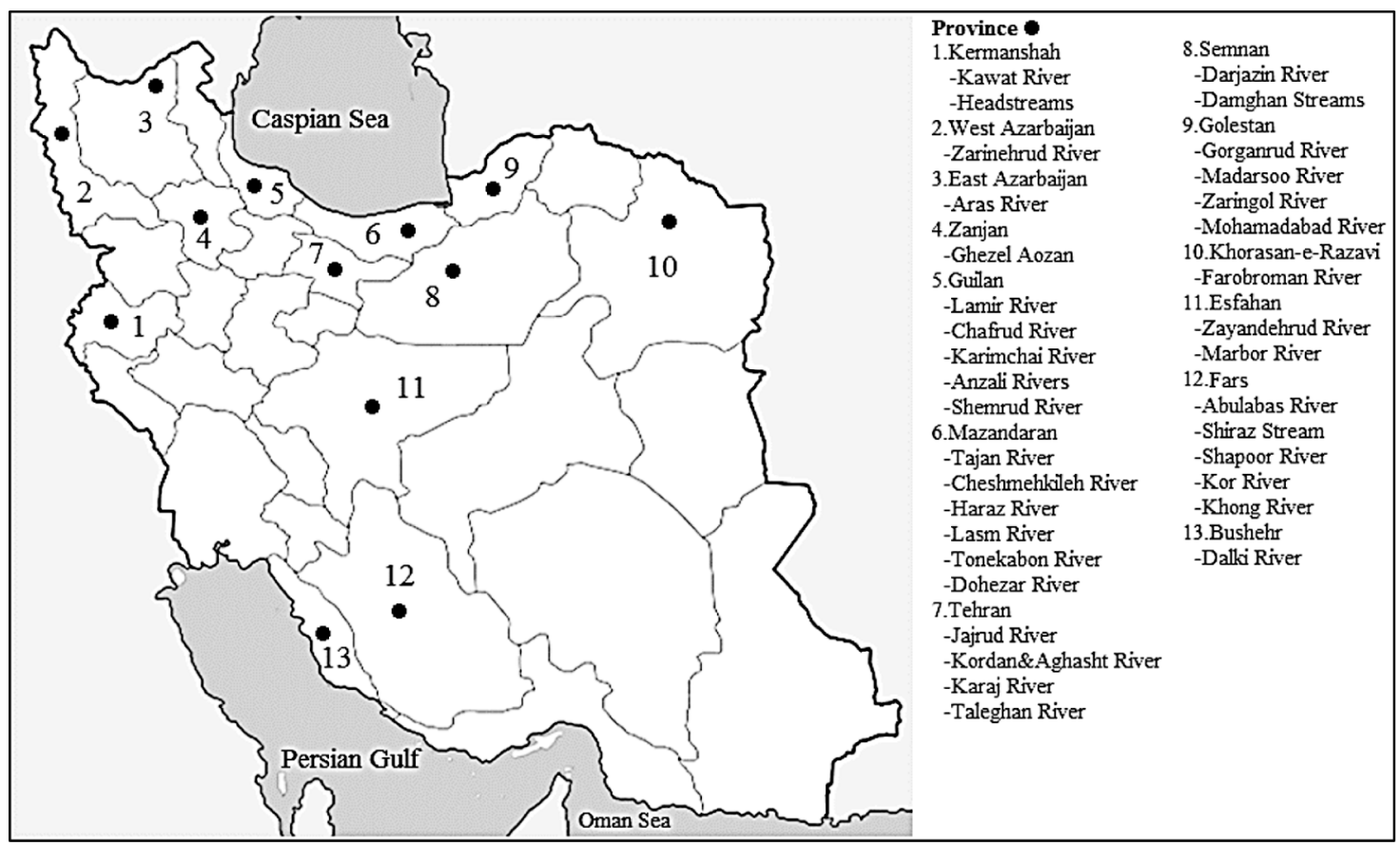

Figure 2. Map of Iran, showing the name of total rivers and streams in each province that recorded species composition of the macroinvertebrate. 
Raoshan Tabari et al., 2013; Shokri et al., 2014). A set of studies also endeavored to address pollution issue and assessment of water quality based on biotic indices and physico-chemical parameters (Gahane et al., 2006; Abbaspoor et al., 2013a; Bashti \& Ostovan, 2014). Such environmental studies looked for the benthic faunal responses against physicochemical variations and pollution loads. For instance, Nadushan \& Ramezani (2011) and Soofiani et al. (2012) reported the macrobenthic communities of the Kordan Stream and the Zayandehrud River, respectively. Furthermore, a set of studies also investigated the biological assessment of rivers based on the population and community structure of benthic macroinvertebrate species (Varnosfaderany et al., 2010; Naderi Jolodar et al., 2011; Sharifinia et al., 2012a; Sharifinia et al., 2012b).

\section{International Significance of the Macroinvertebrate Assemblages}

The macroinvertebrate assemblages of Iran's freshwaters differs from that in other parts of the world in several respects. Some groups of macroinvertebrates that are common in the Northern Hemisphere are absent from or poorly represented in Iran. For instance, the stonefly fauna is dominated by large species belonging to the northern hemisphere families Perlodidae and Perlidae, and there are none of the small Gripopterygidae and Notonemouridae stoneflies that are commonly encountered in southern hemisphere countries. Furthermore, the number of dragonfly species is very small for a country the size of Iran, and many predominantly lotic families of Hemiptera, Gastropoda and Crustacean are poorly represented. In contrast, the Diptera and Ephemeroptera faunas are diverse in Iran, and caddis flies at least. Our hypothesis for the higher diversity of these invertebrates is that speciation process has been facilitated by the abundance and variety of streams and rivers.

\section{Characteristics of the Macroinvertebrate Assemblages in the Iranian Running Waters}

Included in the list of the macroinvertebrate species found in Iranian running waters are taxa which have been previously documented to the genus or species level (Table 1). A total of 158 genera and 126 species belonging to 97 families are primarily composed of three major faunal groups: Arthropoda ( $\mathrm{n}=104$ species; 129 genera), Mollusca ( $\mathrm{n}=19$ species; 14 genera) and Annelida $(\mathrm{n}=2$ species; 13 genera). The phylum Arthropoda was found to be the richest taxonomic group with 104 species, accounting for $82 \%$ of the total macroinvertebrate species and genera (Figure 3). The number of species $(n=103)$ and genera $(n=128)$ in the insecta class were counted and presented in Figure 4 . The highest percentage of genera (46\%) and species $(40 \%)$ were belonging to Diptera order, with the rest including: Ephemeroptera, Plecoptera, Odonata, Hemiptera, Thrichoptera and Hymenoptera (Figure 4).

\section{Threats to Running Waters Macroinvertebrates}

Processes that threaten the biodiversity in freshwater species have been classified into three categories (Collen et al., 2014): habitat loss/degradation, water pollution and
Family

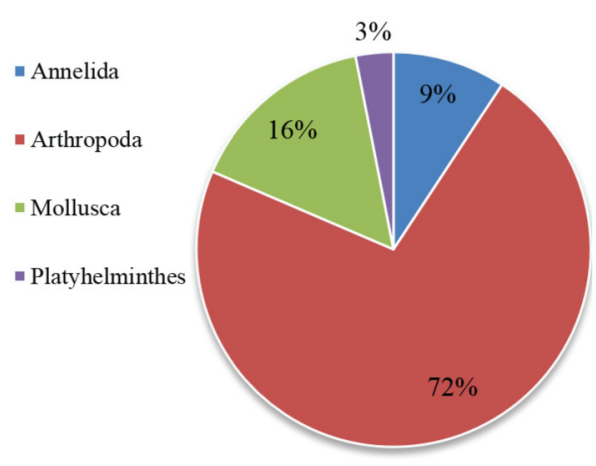

Genus

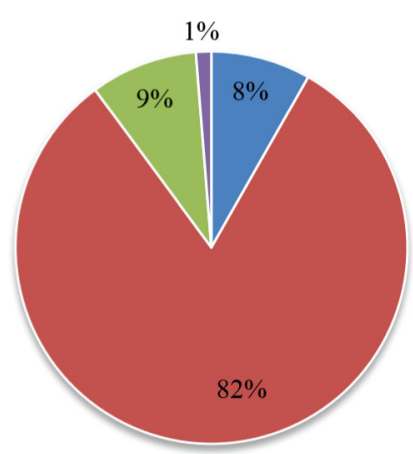

Species

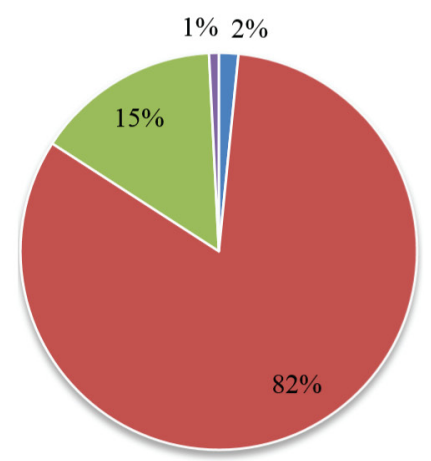

Figure 3. Macroinvertebrate recorded in the Iranian running waters, showing the species, genus and family composition; a total of 4 phyla encompassing 126 species, 158 genus, 97 family, 25 order and 7 classes identified from the meta-data extracted from 57 articles listed in Table 1 and Figure 1. 
over-exploitation. In addition to this factors, invasion of alien species and climate change are also affecting on biodiversity of species in running waters. Of these, the main proximate drivers of habitat loss and degradation were agriculture, urbanization, infrastructure development (particularly the building of dams) and logging (Collen et al., 2014). Up to now, the main factors threatening the aquatic macroinvertebrates in Iran could be including: household sewage, urban waste water, agricultural effluents and habitat degradation by human-induced modifications to the catchment and changes to water quality and river flows. Development of catchments to improved pasture, and associated changes in water temperature and level of enrichment, were identified as important factors influencing the composition of benthic macroinvertebrate assemblages. Channelisation of rivers may also lead to marked changes in macroinvertebrate assemblages, and abstraction of water or altered flow regimes have been found to cause depletion of the macroinvertebrate assemblages in some rivers.

Aquatic invertebrates play a key role in many ecosystem processes such as nutrient cycling and organic matter decomposition. Thus, they are widely used as an indicator of the ecological status of running waters ecosystems. A recent study showed that particularly aquatic invertebrates are at risk from effects of toxicants in the EU, with pesticides playing a dominant role (Malaj et al., 2014). Many studies have reported adverse effects of pollutants on runnig waters macroinvertebrate species or assemblages. These include point source pollutants from agriculture (e.g., Sharifinia et al., 2015), organic effluents (e.g., Álvarez-Cabria et al., 2011), mine drainage (He et al., 2015), and herbicides and pesticides (Magbanua et al., 2013; Bunzel et al., 2015). However, it unlikely that any river-dwelling species has been driven extinct by chemical pollution alone, although this may be a serious problem for species with highly restricted ranges that are also threatened by other factors such as habitat degradation. Few studies have quantitatively documented the impacts of alien aquatic plants and animals on the native fauna of Iran's freshwaters, but it is likely that these have had some adverse effects through predation, competition for food or space, and through habitat degradation.

\section{Future Research Directions}

Running waters macroinvertebrates are recognized as a group of freshwater organisms that have ecological importance as food sources in rivers and streams. Macroinvertebrates studies have a long tradition in freshwater science, with a publication history of over 50 years worldwide existing, with mainstream topics of assemblage, dynamics, production and food web. As part of the present work, the comparative analysis, between worldwide and Iranian studies, on the status quo of scientific publications were provided and briefly discussed, to identify and narrow down the future research directions. However, we analyzed the

\section{Insecta Genera}

\section{Insecta Species}

$\square$ Diptera
Ephemerptera
$\square$ Plecoptera
- Odonata
$\square$ Hemiptera
$\square$ Trichoptera
$\square$ Hymenoptera
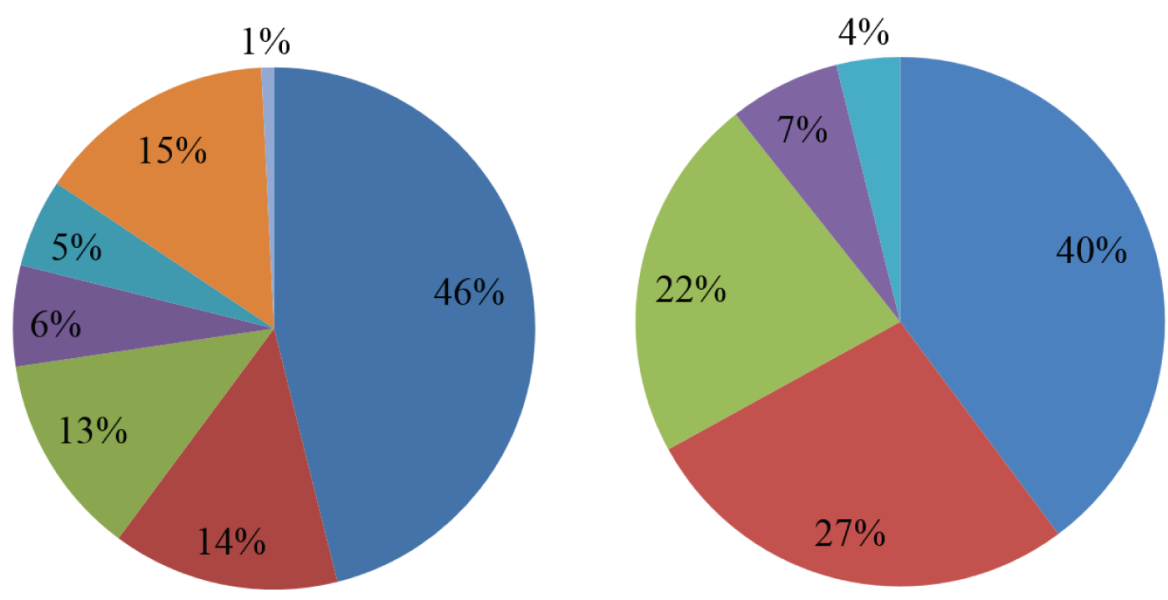

Figure 4. Percentage of genera and species belonging to insecta class recorded by 14 regions and identified from the meta-data extracted from 57 articles. 
most recent 15 years of domestic and international publications only to focus on recent development and limitations, which might be appropriate to identify future challenges in Iran. Furthermore, the scientific papers are highly biased toward the fundamental understanding of macroinvertebrates structure changes in assemblages more than half of the total publications. One major weakness of macroinvertebrates studies in Iran would be a lack of scientific community with widespread but limited group(s) or individuals, and further lesser cooperation between Iranian scientists compared to those in Europe and North America would have blocked the scientific development and published articles in journals with high quality. Nevertheless, individual scientific efforts in Iran's are continuously growing with wider range of topics, in parallel to an appropriate increase in the total number of international publications.

\section{Conclusions}

In the present review, a set of 57 macroinvertebrate studies conducted at the rivers and streams of Iran over the past 15 years has been revisited by an analysis combined with a taxonomic reidentification. A provisioning of comprehensive Iranian macroinvertebrate checklist was first provided as partial outcome of the present review (Table 1). Ongoing efforts in the Iranian running waters regarding biomonitoring indices development, testing, refinement and validation are yet to be employed in streams and rivers. Apart from few ecological and taxonomical studies conducted in patches of the Iranian running waters, there is no effort that has led to the development of biomonitoring indices for the Iranian river and stream ecosystems. The presence of technical, financial and logistical constraints have hindered the potential use of macroinvertebrate communities as indicators of water quality and thus, making biomonitoring programs a remote possibility in the Iranian running waters.

The main threats to freshwater macroinvertebrates in Iran now and in the feature could be including: habitat degradation by catchment clearance and removal of riparian vegetation, wetland drainage, channel engineering works, diffuse and point source pollution, mining and the regulation of flow volumes and patterns. The impacts of alien organisms may also have had significant impacts on some aquatic macroinvertebrates through predation, competition and habitat alteration. Macroinvertebrate species with large, slow-moving larval or adult stages may be particularly susceptible to predation by alien invertebrates, fish and birds. Predation by alien species and the effects of climate change may become increasingly important threats to freshwater invertebrates in the future.

We recommend the following suggestions for future study in the Iranian running waters, (I) technical efforts to develop field standard operating protocols and procedures as well as the establishment of reference conditions for Iranian rivers and streams by a recognized governing body or certified by ISO protocols, covering benthic organisms, (II) balancing efforts to investigate for a more even distribution of species and localities along the Iranian running waters, and finally (III) strong efforts to publish data in peer-reviewed journals.

Because of the lack of information on distribution and ecology of many aquatic macroinvertebrates, I advocate a habitat- rather than a species-based approach to freshwater macroinvertebrate conservation. With endangered species, short-term management usually requires species-based approaches, but longer term conservation success requires a habitat-based approach addressing the needs of that species across its lifetime and that of subsequent generations. Physically undamaged sections of large, unmodified lowland rivers and small streams are now rare in most parts of the country, and numbers of relatively unmodified coastal streams and freshwaters without alien species are also diminishing. If we are to protect remaining examples of these endangered habitats and the aquatic fauna that colonizes them, potentially high-value stations in different regions of the country will need to be identified, given protection, and, if practical, rehabilitated.

\section{Acknowledgements}

Warm thanks directed to Amirali Mordinasb for being considerate and friendly mentor while extracting data from articles for writing this manuscript. Earlier version of this manuscript was improved considerably after the valuable comments and corrections of the scientific editor and two anonymous reviewers.

\section{References}

ABBASI, V., KAMALI, A., GHORBANI, R. and NABAVI, S. The use of multi metric index for pollution detection by use of geographic information system. Global Journal of Environmental Research, 2013a, 7, 13-16. 
ABBASI, V., KAMALI, A., GHORBANI, R. and NABAVI, S.E. The use of multi metric index for pollution tracing by use of geographic information system. Scientific Journal of Environmental Sciences, 2013b, 2, 63-69.

ABBASPOOR, R.A., HAMIDREZA, A.S., HEDAYATIFARD, M. and MESGARAN KARIMI, J. Biological evaluation of river Cheshmekile Tonkabon (Mazandaran province) using biological indicators, population structure and biomass of benthic macro invertebrates. Iranian Journal of Aquatic and Fisheries, 2011, 2, 63-75 [in Persian].

ABBASPOOR, R.A., HASANZADEH, H., HAMIDREZA, A.S., HEDAYATIFARD, M. and MESGARAN KARIMI, J. Assessment of water quality in Cheshmekile River using benthic invertebrates and physicochemical parameters of water. Iranian Journal of Development of aquaculture, 2013a, 7, 43-56 [in Persian].

ABBASPOOR, R.A., HEDAYATIFARD, M., HAMIDREZA, A.S., HASANZADEH, H. and MESGARAN KARIMI, J. Assessment of biotic and water quality indices in Cheshmekile Tonkabon River using benthic invertebrates communities and the physical and chemical parameters of water. Iranian Journal of Environmental Science and Engineering, 2013b, 1, 59-73 [in Persian].

ABBASPOOR, R.A., HEDAYATIFARD, M., MESGARANKARIMI, J. and TOOSI, A. Effects of pollution on the benthic macroinvertebrates in Cheshmekile Tonkabon River based on biological indices. Iranian Journal of Animal Biology, 2012, 4, 55-68 [in Persian].

ABBASPOUR, R., HEDAYATIFARD, M., SABET, H.R.A., HASSANZADEH, H. and KARIMI, J.M. Bioassessment of Macrobenthic Fauna of the Cheshmeh Kileh River, Northern Iran. AmericanEurasian Journal of Agricultural \& Environmental Sciences, 2013, 13(6), 747-753.

ADÁMEK, Z. and MARŠÁLEK, B. Bioturbation of sediments by benthic macroinvertebrates and fish and its implication for pond ecosystems: a review. Aquaculture International, 2013, 21(1), 1-17. http:// dx.doi.org/10.1007/s10499-012-9527-3.

AHMADI, M.R., KAMALI, M. and KAZEMI, R. A study of biomass determination and productivity estimation in the Aghasht and Kordan Rivers (Iran). Iranian Journal of Natural Resources, 2000, 53, 3-20 [in Persian].

AHMADI, R., ALIYEV, A., SEIDGAR, M., BAYRAMOV, A. and GANJI, S. Macroinvertebrate communities differences on riverine parts and reservoirs of Zarrineh River. American Journal of Agricultural and Biological Sciences, 2012, 7(1), 71-75.

ALIYEV, A. and AHMADI, R. Biodiversity of benetic invertebrates in Aras River. Iranian Journal of Fisheries Sciences, 2010, 19, 131-142 [in Persian].
ÁLVAREZ-CABRIA, M., BARQUÍN, J. and JUANES, J.A. Microdistribution patterns of macroinvertebrate communities upstream and downstream of organic effluents. Water Research, 2011, 45(3), 1501-1511. http://dx.doi.org/10.1016/j.watres.2010.11.028. PMid:21168894.

AMINMANSOUR, M. Drought and desertification in Iran [online]. Iran: Pars Times, 2007 [viewed 26 Dec. 2007]. Available from: http://www.parstimes.com/ environment/desertification iran.html

AMRI, N., JAMILI, S. and ABDOLBAGHIAN, S. Diversity of macrobenthos communities and their relationships with environmental factors in Jajroud River, Iran. Resources and Environment, 2014, 4(2), 95-103.

APARICIO, E., CARMONA-CATOT, G., MOYLE, P.B. and GARCÍA-BERTHOU, E. Development and evaluation of a fish-based index to assess biological integrity of Mediterranean streams. Aquatic Conservation: Marine and Freshwater Ecosystems, 2011, 21(4), 324-337. http://dx.doi.org/10.1002/ aqc. 1197.

ARDALAN, A., MOORAKI, N. and SADEGHI, M. Occurrence of Ophidonais serpentina in Potamon persicum from Jajrood River, Iran. Iranian Journal of Fisheries Sciences, 2011, 10(1), 177-180.

B A B A P O O R, M ., M A H D AVI, M ., JAVANSHIR, A., BAZRAFSHAN, O. and MOHAMMADZADEHKHANI, H. Assessment the impact of dams on water quality and diversity of benthic invertebrates in Taleghan River. Iranian Journal of Rangeland and Watershed, 2011, 64, 129143 [in Persian].

BASHTI, H. and OSTOVAN, H. Estimation of field Biotic Index and Water Quality of streams in North west of Shiraz region, Iran using Aquatic Insect fauna. International Research Journal of Applied and Basic Sciences, 2014, 8, 516-518.

BUNZEL, K., SCHÄFER, R.B., THRÄN, D. and KATTWINKEL, M. Pesticide runoff from energy crops: a threat to aquatic invertebrates? The Science of the Total Environment, 2015, 537, 187-196. http://dx.doi.org/10.1016/j.scitotenv.2015.08.011. PMid:26282752.

CHANG, F.-H., LAWRENCE, J.E., RIOS-TOUMA, B. and RESH, V.H. Tolerance values of benthic macroinvertebrates for stream biomonitoring: assessment of assumptions underlying scoring systems worldwide. Environmental Monitoring and Assessment, 2014, 186(4), 2135-2149. http://dx.doi. org/10.1007/s10661-013-3523-6. PMid:24214297.

COLLEN, B., WHITTON, F., DYER, E.E., BAILLIE, J.E., CUMBERLIDGE, N., DARWALL, W.R., POLLOCK, C., RICHMAN, N.I., SOULSBY, A.M. and BÖHM, M. Global patterns of freshwater species diversity, threat and endemism. Global Ecology 
and Biogeography, 2014, 23(1), 40-51. http://dx.doi. org/10.1111/geb.12096. PMid:26430385.

EBRAHIMNEJAD, $M$. and NIKOO, H. Macroinvertebrate taxonomic identification and distribution in Marbor River. Iranian Journal of Biology, 2004, 17, 247-260 [in Persian].

EBRAHIMNEJAD, M. Macroinvertebrate diversity and abundance and biotic indices in Zayandehrud River. Iranian Journal of Biology, 2003a, 15, 31-42 [in Persian].

EBRAHIMNEJAD, M. Macroinvertebrate Identification in Zayandehrud River. Iranian Journal of Science, 2003b, 17, 61-72 [in Persian].

EBRAHIMNEZHAD, M. and FAKHRI, F. Taxonomic study of Chironomidae (Diptera) larvae of Zayandehrood River, Iran, and effects of selected ecological factors on their abundance and distribution. Iranian Journal of Science \& Technology, 2005, 29, 89-105.

FARASAT, H. and SHARIFI, M. Food habit of the endangered yellow-spotted newt Neurergus microspilotus (Caudata, Salamandridae) in Kavat Stream, western Iran. Zoological Studies (Taipei, Taiwan), 2014, 53(1), 61. http://dx.doi.org/10.1186/ s40555-014-0061-z.

FARHANGI, M. and TAIMOORI YANSARI, M. Identification benthic invertebrate Mohammad Abad River (Golestan province). Iranian Journal of Animal Biology, 2012, 4, $51-52$ [in Persian].

GAHANE, A., AHMADI, M.R., ESMAEILI, A. and MIRZAJANI, A.R. Biological evaluation Chafrood River (Guilan province) using the Macrobenthic Community. Iranian Journal of Science and Technology of Agriculture and Natural Resources, 2006, 10, 247 258 [in Persian].

GHASEMI, A.F. and KAMALI, M. Benthic macroinvertebrates along the haraz downstream in southern caspian sea basin: In gradient of the physicochemical parameters. International Journal of Zoology, 2014, 2014, 1-7.

GOUDIE, A.S. The human impact on the natural environment: past, present, and future. Hoboken: John Wiley \& Sons, 2013.

HAFEZIYEH, M. Aquatic insects as indicators of water pollution. Iranian Journal of Fisheries Sciences, 2001, 10, 19-36 [in Persian].

HAFFAR, M., AHMADI, M.R. and YAHYAVI, Y. Bioassessment of Kor river (Fars province) in different seasons by use Community Structure Macrobenthic. Scientific Journal of Aquatic Organisms and Fisheries, 2010, 1, 21-34 [in Persian].

HATAMI, R., MAHBOOBI SOFYANI, N., EBRAHIMI, E. and HOMAMI, M.R. Evaluate the impact of aquaculture effluents on macroinvertebrate communities and water quality of the Zayandehrood
River using BMWP index. Iranian Journal of Environmental Science, 2011a, 37, 43-54 [in Persian].

HATAMI, R., MAHBOOBI SOOFIANI, N., EBRAHIMI, E. and HEMAMI, M. Evaluating the aquaculture effluent impact on macroinvertebrate community and water quality using BMWP index. Journal of Environmental Studies, 2011b, 37, 13.

HE, F., JIANG, W., TANG, T. and CAI, Q. Assessing impact of acid mine drainage on benthic macroinvertebrates: can functional diversity metrics be used as indicators? Journal of Freshwater Ecology, 2015, 30(4), 1-12.

HOSYNI, S.A., OSTOVAN, H. and HOSSEINI, S.E. Estimation of field biotic index and water quality of Khong River in Sepidan Region by using aquatic insects fauna. Plant Protection Journal, 2012, 4, 2936 [in Persian].

HOSYNI, S.M. and NEJAD, R.A. Determination the effects of sand making site on river pollution by biotic indices (case study: Talar River, Mazandaran). Spectrum (Lexington, Ky.), 2014, 3(9), 60-73.

JOHNSON, S. and RINGLER, N. The response of fish and macroinvertebrate assemblages to multiple stressors: A comparative analysis of aquatic communities in a perturbed watershed (Onondaga Lake, NY). Ecological Indicators, 2014, 41, 198-208. http://dx.doi.org/10.1016/j.ecolind.2014.02.006.

JORJANI, S., GHELICHI, A., AKRAMI, R. and KHEIRABADI, V. Bioassessment index and Macrobenthoses fauna of Madarsu stream, National Park of Golestan. Indian Journal of Fisheries, 2008, 2, 41-52 [in Persian].

KAMALI, M. and ESMAEILISARI, A. Biological evaluation Lasem River (Amol - Mazandaran province) based on benthic invertebrates. Iranian Journal of Biology Science, 2009, 3, 51-61 [in Persian].

KAMALI, S.A. and TATINA, M. Assessment of the water quality of Lamir River - Tlesh city using benthic aquatic insect communities. Wetlands, 2010, 2, 3-12 [in Persian].

KAMALI, S.A., STONE, H. and TATINA, M. Assessment of the water quality of Karimchai, Chelevand Lavandevil - Astara city using benthic aquatic insect communities. Wetlands, 2010, 1, 7989 [in Persian].

KHATAMI, S. and SHAYEGAN, S. Physico-chemical and biological characteristics of Sarabs (spring pools) in the Kermanshah Province of Iran. Iranian Journal of Science \& Technology, Transaction B, Engineering, 2006, 30, 621-635 [in Persian].

KHATAMI, S.H., RIYAZI, B. and MODIRIASARI, S.A. Water quality assessment of Karaj River based on macroinvertebrate diversity. Iranian Journal of Environmental Science and Technology, 2007, 9, 7178 [in Persian]. 
KIM, T.-W., KIM, D., BAEK, S.H. and KIM, Y.O. Human and riverine impacts on the dynamics of biogeochemical parameters in Kwangyang Bay, South Korea revealed by time-series data and multivariate statistics. Marine Pollution Bulletin, 2015, 90(1-2), 304-311. PMid:25481735.

MAGBANUA, F.S., TOWNSEND, C.R., HAGEMAN, K.J. and MATTHAEI, C.D. Individual and combined effects of fine sediment and the herbicide glyphosate on benthic macroinvertebrates and stream ecosystem function. Freshwater Biology, 2013, 58(8), 1729-1744. http://dx.doi.org/10.1111/fwb.12163.

MALAJ, E., VON DER OHE, P.C., GROTE, M., KÜHNE, R., MONDY, C.P., USSEGLIOPOLATERA, P., BRACK, W. and SCHÄFER, R.B. Organic chemicals jeopardize the health of freshwater ecosystems on the continental scale. Proceedings of the National Academy of Sciences of the United States of America, 2014, 111(26), 9549-9554. http://dx.doi. org/10.1073/pnas.1321082111. PMid:24979762.

MCCLUNEY, K.E., POFF, N.L., PALMER, M.A., THORP, J.H., POOLE, G.C., WILLIAMS, B.S., WILLIAMS, M.R. and BARON, J.S. Riverine macrosystems ecology: sensitivity, resistance, and resilience of whole river basins with human alterations. Frontiers in Ecology and the Environment, 2014, 12(1), 48-58. http://dx.doi.org/10.1890/120367.

MEHRABY, R. Rivers of Iran [online]. Iran: DestinationIran, 2010 [viewed 17 Mar. 2010]. Available from: http://www.destinationiran.com/ tag/rivers-of-iran

MENETREY, N., OERTLI, B. and LACHAVANNE, J.-B. The CIEPT: a macroinvertebrate-based multimetric index for assessing the ecological quality of Swiss lowland ponds. Ecological Indicators, 2011, 11(2), 590-600. http://dx.doi.org/10.1016/j. ecolind.2010.08.005.

MESGARANKARIMI, J., AZARI TAKAMI, G., KHARA, H. and ABBASPOOR, R.A. Determining benthic macroinvertebrate diversity and abundance of Dohezare Tonekabon River using biological indices. Iranian Journal of Aquatic and Fisheries, 2012a, 3, 27-39 [in Persian].

MESGARANKARIMI, J., AZARI TAKAMI, G., KHARA, H. and ABBASPOOR, R.A. Effect of aquaculture effluent on benthic macroinvertebrate biodiversity in Dohezare Tonkabon River. Iranian Journal of Animal Biology, 2012b, 5, 37-49 [in Persian].

MIRRASOULI, E., GHORBANI, R. and ABBASI, F. The Biological Assessment of the Zaringol Stream Using the Structure of Benthic Macroinvertebrates (Golestan Province). Journal of Fisheries. Iranian Journal of Natural Resources, 2012a, 64, 357-369. [in Persian]

MIRRASOULI, E., NEZAMI, S.A., KHARA, H. and GHORBANI, R. The impact of aquaculture effluent from rainbow trout (Oncorhynchus mykiss) farms on the benthic invertebrates in Zarin Gol River. Iranian Journal of Development of Aquaculture, 2012b, 6, 8192 [in Persian].

MIRZAJANI, A., GHANESASANSARAI, A. and KHODAPARAST, S.H.A. Water quality assessment of rivers drains to Anzali Lagoon based on macroinvertebrate communities. Iranian Journal of Environmental Studies, 2008, 34, 31-38 [in Persian].

MONTAJAMI, S., HOSSEINI, S.A., GHORBANI, R. and MEHDIZADEH, M. Investigation of some physicochemical characteristics of Farobroman River water by using benthic macroinvertebrates as biological indicator. World Journal of Fish and Marine Sciences, 2012, 4, 645-650.

MOYA, N., HUGHES, R.M., DOMÍNGUEZ, E., GIBON, F.-M., GOITIA, E. and OBERDORFF, T. Macroinvertebrate-based multimetric predictive models for evaluating the human impact on biotic condition of Bolivian streams. Ecological Indicators, 2011, 11(3), 840-847. http://dx.doi.org/10.1016/j. ecolind.2010.10.012.

MUNNÉ, A. and PRAT, N. Effects of Mediterranean climate annual variability on stream biological quality assessment using macroinvertebrate communities. Ecological Indicators, 2011, 11(2), 651-662. http:// dx.doi.org/10.1016/j.ecolind.2010.09.004.

NADERI JOLODAR, M., ABDOLI, A., MIRZAKHANI, M.K. and SHARIFI JOLODAR, R. Benthic Macroinvertebrates Response in the Haraz River to the trout farms effluent. Iranian Journal of Natural Resources, 2011, 64, 163-175 [in Persian].

NADUSHAN, R.M. and RAMEZANI, M. Bioassessment of Kordan Stream (Iran) water quality using macro-zoobenthos indices. International Journal of Biology, 2011, 3, 127.

NAMIN, J.I., SHARIFINIA, M. and MAKRANI, A.B. Assessment of fish farm effluents on macroinvertebrates based on biological indices in Tajan River (north Iran). Caspian Journal of Environmental Sciences, 2013, 11, 29-39.

NAVAN MAGHSOODI, M. Study on Bentic organisms of Ghazal Ozan River in Zanjan Province. Iranian Scientific Fisheries Journal, 2012, 21, 125-138 [in Persian].

NAVAN MAGHSOODI, M., AHMADI, M.R. and KAIVAN, A. Assessment of production potential using benthic abundance and diversity in Shemrood Siahkal River. Iranian Journal of Fisheries Sciences, 2003, 12, 123-138 [in Persian].

OSTOVAN, H. and NIYAKAN, J. Determination of biotic indices and water quality using aquatic insect fauna in Shapoor River. Iranian Journal of Agriculture Sciences, 2007, 13, 683-691 [in Persian].

PALLER, M.H., STERRETT, S.C., TUBERVILLE, T.D., FLETCHER, D.E. and GROSSE, A.M. 
Effects of disturbance at two spatial scales on macroinvertebrate and fish metrics of stream health. Journal of Freshwater Ecology, 2014, 29(1), 83-100. http://dx.doi.org/10.1080/02705060.2013.832707.

PAZIRA, A., EMAMI, S.M., KOUHGARDI, E., VATANDOOST, $S$. and AKRAMI, R. The effect of the environmental parameters on biodiversity of macrobentose in Dalaki and Helle river of Boushehr. Indian Journal of Fisheries, 2008, 2, 65-70.

PERERA, R., WATTAVIDANAGE, J. and NILAKARAWASAM, N. Development of a macroinvertebrate-based Index of Biotic Integrity (M-IBI) for Colombo-Sri Jayawardhanapura canal system (a new approach to assess stream/wetland health). Journal of Tropical Forestry and Environment, 2012, 2(1), 10-19.

RAOSHAN TABARI, M., SOLAIMANROODI, A., SHARAFI, S. and ROHANI ARDASHIRI, R. Effects of sand exploitation on benthic invertebrates in the Tonkabon River. Iranian Journal of Animal Biology, 2013, 6, 9-16 [in Persian].

SHAPOORI, M., ZOLARYASTIN, N. and AZARBAD, H. Rapid assessment of water quality in Gorganroud River based on biological indices. Iranian Journal of Sciences and Techniques in Natural Resources, 2010, 5 , 115-129 [in Persian].

SHARIFINIA, M., MAHMOUDIFARD, A., GHOLAMI, K., NAMIN, J. and RAMEZANPOUR, Z. Benthic diatom and macroinvertebrate assemblages, a key for evaluation of river health and pollution in the Shahrood River, Iran. Limnology, 2015. http://dx.doi.org/10.1007/ s10201-015-0464-5.

SHARIFINIA, M., NAMIN, J.I. and BOZORGI, A. Ecological assessment of the Tajan River using feeding groups of benthic macroinvertebrates and biotic indices. Iranian Journal of Applied Ecology, 2012a, 1, 80-95 [in Persian].

SHARIFINIA, M., NAMIN, J.I. and MAKRANI, A.B. Benthic macroinvertabrate distribution in Tajan River using canonical correspondence analysis. Caspian Journal of Environmental Sciences, 2012b, 10, 181-194.

SHOKRI, M., ROSSARO, B. and RAHMANI, H. Response of macroinvertebrate communities to anthropogenic pressures in Tajan River (Iran).
Biologia, 2014, 69(10), 1395-1409. http://dx.doi. org/10.2478/s11756-014-0448-7.

SOLTANI, F., NADERI JOLODAR, M., VOSOOGHI, A.R. and DARVISHBASTAMI, K. Comparison of the effects of sand mining activities and rainbow trout farming effluent on benthic macroinvertebrate population structure in Haraz River. Iranian Journal of Animal Environmental, 2012, 4, 25-34 [in Persian].

SOOFIANI, N.M., HATAMI, R., HEMAMI, M. and EBRAHIMI, E. Effects of trout farm effluent on water quality and the macrobenthic invertebrate community of the Zayandeh-Roud River, Iran. North American Journal of Aquaculture, 2012, 74(2), 132-141. http://dx.doi.org/10.1080/15222055.201 2.672367 .

TOOSI, A., SHAJIEE, H., GHELICHI, A. and SABERI, S.E. Evaluation of water quality in six springs northen Damghan based on the variety of Macrobenthics. Journal of Fisheries, Islamic Azad University. Azadshahr Branch, 2011, 5, 1-16 [in Persian],

VARNOSFADERANY, M.N., EBRAHIMI, E., MIRGHAFFARY, N. and SAFYANIAN, A. Biological assessment of the Zayandeh Rud River, Iran, using benthic macroinvertebrates. LimnologicaEcology and Management of Inland Waters, 2010, 40(3), 226-232. http://dx.doi.org/10.1016/j. limno.2009.10.002.

WEI, J. and HE, X. The impacts of human activities on riverine sediment load: a case study of the Upper Yangtze River Basin. Journal of Geographical Research, 2012, 110, 1-12.

WEIGEL, B.M. and DIMICK, J.J. Development, validation, and application of a macroinvertebratebased Index of Biotic Integrity for nonwadeable rivers of Wisconsin. Development, 2011, 30, 665-679.

YAZDIAN, H., JAAFARZADEH, N. and ZAHRAIE, B. Relationship between benthic macroinvertebrate bio-indices and physicochemical parameters of water: a tool for water resources managers. Journal of Environmental Health Science \& Engineering, 2014, 12(1), 30. http://dx.doi.org/10.1186/2052336X-12-30. PMid:24410768.

Received: 19 April 2015 Accepted: 11 December 2015 